\title{
ALGORITMIC AND APPLICATION COMPUTER SKILLS OF SECONDARY SCHOOL GRADUATES
}

\author{
Hana HAVELKOV $\boldsymbol{A}^{*}$, Jihočeská univerzita v Českých Budějovicích
}

Přijato: 22. 3. 2016 / 15. 6. 2016

Typ článku: Výzkumný článek

DOI: $10.5507 /$ jtie.2016.017

\begin{abstract}
The paper is concerned on problem of detecting and comparing output informatics skills of secondary school graduates in the context of inconsistent school educational programs; it mentions the necessity of establishing unified output skills, lists some of testing tools used in schools. The author introduces the Hungarian didactic test which was used for testing current algorithmic and application computer skills of freshmen of tertiary IT studies. The appropriateness of using this test in Czech Republic in order to find out the current status quo is considered. The author discusses this informatics test, analyses some particular tasks, and reveals the results of the first experimental testing among some IT students of West Bohemia University and South Bohemia University. A group of primary and secondary school teachers took part in the project, too, so students' results are compared not only between these two universities groups, but within groups with respect to students' self-assessments and teachers' prognosis.
\end{abstract}

Key words: IT, test, algorithmic skills, application computer skills

\section{ALGORITMICKÉ A UŽIVATELSKÉ POČÍTAČOVÉ DOVEDNOSTI ABSOLVENTŮ STŘEDNÍCH ŠKOL}

Resumé: Článek se zaměruje na problematiku zjištování a porovnávání výstupních „informatických" dovedností absolventů střednich škol v kontextu nekonzistentnich školnich vzdèlávacích programů, zmiñuje potřebu stanoveni jednotných výstupních kompetencí, uvádí testovaci nástroje použivané na školách. Představuje mad’arský didaktický test použitý pro testování aktuálních algoritmických a uživatelských počitačových dovedností studentů prvních ročníku IT oborů vysokých škol. Autor diskutuje uvedený informatický test, analyzuje jeho úlohy, zvažuje vhodnost jeho nasazení $v$ Česku. Uvádi výsledky pokusného testováni mezi studenty IT oborì Západočeské a Jihočeské univerzity, porovnává výsledky studentů z obou univerzit a zároveň konfrontuje jejich výsledky s výsledky skupiny učitelů základních a střednich škol, kteři se testu též účastnili, a to s ohledem na jejich prognózy a sebehodnocení.

Klíčová slova: IT, algoritmické dovednosti, uživatelské počítačové dovednosti

*Autor pro korespondenci: havelkova@pf.jcu.cz 


\section{1 Úvod}

Ke studiu informatiky na českých vysokých školách se každoročně hlásí uchazeči $\mathrm{z}$ nejrůznějších typů středních škol $\mathrm{s}$ velmi rozdílnou úrovní "informatických dovedností". Studenti nastupují s různou klasifikací svých schopností, s různou či žádnou maturitní zkouškou z informatiky a mnohdy nepřesnou představou o náplni budoucího studia, bývají přijímáni i bez přijímacích zkoušek.

Problémem není pouze rozdílná úroveň IT schopností a dovedností studentů, nýbrž i samotné její zjištění, což je zásadní východisko pro výuku informatických předmětů. Studenti Pedagogické fakulty Jihočeské univerzity v Českých Budějovicích, na níž působím, jsou povinni během prvních dvou let studia absolvovat fakultou daný IT test, který ale není vstupním testem a zjištuje základní uživatelské dovednosti v práci s textem, tabulkami a grafikou. Uvítali jsme tedy nabídku kolegů z Fakulty informatiky Univerzity Debrecín účastnit se jejich mezinárodního projektu TAaAS (Testing Algorithmic and Application Skills), jehož součástí je test algoritmických a uživatelských dovedností. Projekt byl odstartován jako národní, v současné době se jej účastnilo 17 vysokých škol ze 7 států. Předem jsme o projektu měli jen stručné informace od jedné $\mathrm{z}$ autorek testu, takže $\mathrm{z}$ naší strany šlo o pokusné použití testu, jehož validitu jsme mohli pouze předpokládat.

\section{Komparace aktuálního stavu algoritmických a uživatelských dovedností studentů VŠ s výsledky jejich maturitních zkoušek}

Mad’arský projekt TAaAS, v jehož rámci výzkumné šetření probíhalo, je určen studentům prvních ročníků IT oborů vysokých škol. Primárním záměrem bylo porovnat aktuální stav algoritmických a uživatelských dovedností studentů s výsledky jejich maturitních zkoušek. Autorky testu si kladly otázku: "Jak dobře jsou studenti prripraveni pro vysokoškolská studia IT?” (Biró \& Csernoch, 2015)

Maturitní zkoušky jsou v Mad’arsku od roku 2005 jednotné, obsahují povinnou matematiku, do prijímacích zkoušek na IT obory jsou zahrnuty výsledky maturity z matematiky event. informatiky a jiných maturitních předmětů, takže se dalo počítat s jistými standardními výstupy a znalostmi studentů.

V České republice neexistuje momentálně státní a tedy jednotná úroveň maturity z informatiky, matematika povinná není, takže provádět tatáž srovnání jako v Mad’arsku by mohlo být zavádějící, ale účast v projektu se jevila jako příležitost získat zajímavá data, možná objevit nečekané souvislosti, zjistit aktuální znalosti testovaných studentů, na které pak lze navázat při výuce. Lákavá byla i možnost mezinárodního srovnání.

Více než dvě třetiny českých studentů testovaných v projektu TAaAS absolvovalo nějakou formu informatické maturity, takže možnost zkoumat výsledky maturit v kontextu s výsledky testu se ukazovala jako reálná.

Testované uživatelské dovednosti vycházely z úrovně ECDL Core - základní pojmy informačních a komunikačních technologií, použivání počítače a správa souborů, práce $\mathrm{s}$ textovým editorem, práce s internetem a komunikace + práce $\mathrm{s}$ tabulkovým kalkulátorem. (ECDL, 2010) 


\section{Zjišt'ování IT znalostí a schopností, standardizace výstupů}

V Česku momentálně neexistuje jednotný standardizovaný test, který by se dal použít pro měření IT znalostí a schopností žáků na libovolném stupni škol. K jistému otestování IT schopností lze sice použít ECDL test, ale požadavky testu nemusejí nutně odpovídat látce probírané na středních školách a rozhodně ne na základních školách. V roce 2013 se Česko zapojilo do projektu ICILS (International Computer and Information Literacy Study), který poskytl komparativní analýzu výsledků žáků osmých tříd. Žákům 5. a 9. tříd mimopražských škol byl určen projekt Gepard testující informační gramotnost. V roce 2015 byl školám a veřejnosti k dispozici test IT Fitness testující dovednosti z oblasti IKT, který byl k dispozici ve verzi pro základní školy a vyšší verzi pro střední školy a veřejnost.

Výstupní IT dovednosti absolventů středních škol by bylo možně měřit státní maturitní zkouškou z informatiky, která již byla v minulosti nabízena, ale zatím se od ní ustoupilo, což jen dokladuje, jak problematické je sestavit univerzální test IT schopností a dovedností.

Klíčovou otázkou nicméně je: Jak měřit a srovnávat něco, co nemá stanovenou přesně definovanou množinu standardů a výstupů díky tomu, že každá škola si po svém zpracovává své školní vzdělávací programy?

V rámcovém vzdělávacím programu pro základní vzdělávání (RVPZV) z roku 2013, který definuje národní standardy pro základní vzdělávání a vymezuje klíčové kompetence a vzdělávací obsah, jsou formulované očekávané výstupy a nepř́liš detailní přehled učiva. "Učivo, vymezené $\mathrm{v} R \mathrm{RP} \mathrm{ZV}$, je doporučené školám k distribuci a k dalšímu rozpracování do jednotlivých ročníků nebo delších časových úseků. Na úrovni ŠVP se stává učivo závazné." (MŠMT, 2013) A to je právě problém, nebot' na každé konkrétní škole se doporučené učivo může rozpracovat do jiných detailů, mohou se používat jiné aplikace (tabulkové kalkulátory, textové a grafické editory ...).

Ve vzdělávací oblasti Informační a komunikační technologie jsou specifikovány konkrétně pro druhý stupeň ZŠ jisté výstupy jako např.:

Ž́a

- ICT-9-2-01 ovládá práci s textovými a grafickými editory i tabulkovými editory a využívá vhodných aplikací

- $\quad$ ICT-9-2-04 používá informace $\mathrm{z}$ různých informačních zdrojů a vyhodnocuje jednoduché vztahy mezi údaji

Zmíněno je též "používání algoritmického myšlení při interakci s počítačem" (MŠMT, 2013).

RVP gymnázií klade důraz na klíčové kompetence a specifikuje 10 výstupů jako je např.: "Žák

- $\quad$ ovládá, propojuje a aplikuje dostupné prostředky ICT,

- využívá teoretické i praktické poznatky o funkcích jednotlivých složek hardwaru a softwaru k tvưrčímu a efektivnímu řešení úloh,

- zpracovává a prezentuje výsledky své práce s využitím pokročilých funkcí aplikačního softwaru, multimediálních technologií a internetu,

- $\quad$ aplikuje algoritmický př́istup k řešení problémů." (MŠMT, 2007a)

Rámcové vzdělávací plány středních odborných škol nespecifikují konkrétní výstupy, uvádějí cílové znalosti a zmiňují jako základ ECDL. Je zajímavé, že bez ohledu na typ 
školy (obchodní akademie, zemědělská škola, strojní, elektrotechnická,...) př́slušné RVP obsahují v oblasti IKT stejný text a neobsahují vůbec seznam dílčích témat.

Takže co se vlastně z oblasti IKT na školách učí To záleží na konkrétním ŠVP a samožrejmě na konkrétním učiteli, nebot' odlišnosti mohou nastat i uvnitř školy a s rychlým vývojem v oblasti IT i jeden konkrétní učitel nemusí učit každý rok totéž.

Jak můžeme tedy testovat? A lze srovnávat nesrovnatelné? A je rozumné použít cizí test vytvořený $\mathrm{v}$ cizím státě určený žákům $\mathrm{s}$ přesně definovanými výstupy a obsahem v oblasti IKT? A můžeme pak porovnávat výsledky jednotlivých zúčastněných států? Můžeme učinit aspoň pokus.

\section{Použité metody}

Ke sběru dat byla použita explorativní metoda - didaktický test a dotazník, obojí bylo vytvořeno v rámci projektu TAaAS, na sestavování jsme se autorsky nepodíleli, pouze jsme provedli překlad $\mathrm{z}$ angličtiny do češtiny.

Didaktický test zahrnoval výhradně otevřené úlohy z různých oblastí informačních technologií (viz podrobnější rozbor dále v textu).

Dotazník zjištoval data o zkušenostech v oblasti IT, o vzdělání, zájmech, jazykových dovednostech, profesním zaměřní; a byl částečně odlišný pro studenty a pro učitele. Studenti uváděli počty absolvovaných hodin IKT, prípadně výsledky maturity z matematiky a informatiky, dále též odhad svých schopností v oblasti editace textu, práce s tabulkami a algoritmizace. Učitelé informovali o svých vyučovacích aktivitách, uváděli důležitost a prognózu výsledku každé otázky předloženého informatického testu.

Test i dotazník měl papírovou podobu, řešilo se bez použití jakékoliv techniky. Hotové testy a dotazníky byly odeslány $\mathrm{k}$ vyhodnocení prímo mad’arským autorkám na Univerzitu Debrecín, přičemž textové odpovědi byly z češtiny překládány do angličtiny a telefonicky diskutovány s jednou $\mathrm{z}$ autorek testu.

Akceptovali jsme hodnotící systém a autorská řešení, aby byli stejně hodnoceni respondenti ze všech zúčastněných států. Po kompletaci jsme obdrželi tabulky s podrobnými výsledky testu vyhodnocenými dle autorského řešení a též naskenované testy i dotazníky kvůli další kontrole.

Ke zpracování získaných dat byly použity kvantitativní metody, bylo provedeno předzpracování dat (validace, čištění, př́ipadně diskretizace dat).

Byly vypočteny deskriptivní statistiky - četnosti, průměry, rozptyly, byly stanoveny hypotézy a bylo prováděno jejich ověřování (kapitola 9).

U každého z výběrů bylo pomocí Shapiro-Wilkova testu ověřováno, zda pochází z normálního rozdělení. Pro analýzu kategoriálních dat byl použit chí-kvadrát test dobré shody. Pro zjištování síly vztahu dvou spojitých proměnných byl použit Pearsonův korelační koeficient (Hendl, 2006).

Při zjištování shody středních hodnot dvou nezávislých výběrů byla nejprve ověřována homoskedasticita (shoda rozptylů) pomocí Fisherova F-testu; v prŕípadě shody rozptylů byl dále použit Studentův $\mathrm{t}$-test, $\mathrm{v}$ opačném prrípadě Welchův test (Crawley, 2013).

Byla posuzována obsahová validita testu, reliabilita testu byla ověřována pomocí Cronbachova alfa. (Chráska, 2007)

$\mathrm{K}$ výpočtům byl použit tabulkový kalkulátor a free statistický software $\mathrm{R}$. 


\section{Charakteristika výzkumného vzorku}

Česko se k projektu TAaAS přidalo v roce 2014, do testování se zapojila Fakulta pedagogická Západočeské univerzity a Pedagogická fakulta Jihočeské univerzity, jejíž studenti se projektu účastnili jako jediní z Česka i v roce 2015.

V roce 2014 se testování účastnilo 90 českých účastníků: 59 studentů a 31 učitelů:

- 17 studentů prvního ročníku bakalářského oboru Informační technologie se zaměřením na vzdělávání (ITV) ze Západočeské univerzity (ZČU),

- 22 studentů prvního ročníku bakalářského oboru Informační technologie a e-learning (ITE) z Jihočeské univerzity (JČU),

- 20 studentů prvního ročníku bakalářského oboru ITV z JČU,

- $\quad 31$ učitelů základních a středních škol, kteří se v inkriminovaném čase účastnili školení pro IT koordinátory na Pedagogické fakultě JČU.

V roce 2015 se již testu zúčastnila z Česka pouze JČU s celkem 26 studenty prvního ročníku bakalářských oborů.

Následující tabulka ukazuje výsledky informatického testu projektu TAaAS 2014. Celková úspěšnost všech českých účastníků (včetně učitelů) byla pouze $22,2 \%$, a pokud bychom požadovali $50 \%$ na úspěšné absolvování testu, selhali by všichni (žádný český účastník této hodnoty nedosáhl).

\begin{tabular}{|l|r|}
\hline Učitelé & $26,3 \%$ \\
\hline Všichni studenti dohromady & $20,1 \%$ \\
\hline Všichni studenti ZČU & $15,4 \%$ \\
\hline Všichni studenti JČU & $22,0 \%$ \\
\hline Studenti ITV (JČU+ZČU) & $18,6 \%$ \\
\hline Studenti ITE (JČU) & $22,5 \%$ \\
\hline Odhad úspěñnosti (učitelé odhadovali výsledky studentů) & $20,9 \%$ \\
\hline
\end{tabular}

Tab. č. 1: Úspěšnost českých účastniků v testu TAaAS 2014

Z dat tabulky lze usoudit, že učitelé byli úspěšnější než studenti a dále že studenti ZČU dopadli hưre než studenti JČU. Použitím statistických metod (viz níže) bylo zjištováno, do jaké míry jsou tyto závěry relevantní.

\section{Kategorie úloh testu 2014}

TAAS 2014 test obsahoval 11 komplexnějších úloh rozdělených do 5 kategorií: Soubory, Čísla, Tabulky, Zpracování textu a Algoritmy.

Kategorie Soubory zahrnovala úlohy zoblasti běžných operací se soubory a teoretickou otázku týkající se URL.

Kategorie Č́sla byla zaměřena na operace s číselnými soustavami, jako je konverze čísel mezi desítkovou, šestnáctkovou a dvojkovou soustavou, sčíáni v šestnáctkové a dvojkové soustavě.

Kategorie Tabulky tvořily 2 úlohy, obě byly postaveny na znalosti netriviálních funkcí v tabulkovém kalkulátoru, přičemž první vyžadovala jisté algoritmické schopnosti při řešení daných 6 podúloh. 
Kategorie Zpracování textu obsahovala 13 podúloh, které spočívaly v rozpoznání a klasifikaci chyb ve vyznačených partiích textu, který byl celý v mad’arštině a byl zobrazen včetně formátovacích znaků.

Kategorie Algoritmy zahrnovala 3 praktické úlohy s ukázkami algoritmů v pseudokódu či vývojovém digramu, úkolem bylo tyto algoritmy analyzovat.

Zamyslíme-li se nad kategoriemi testu a nad konkrétními úlohami, je výběr poněkud netypický. Kategorie Čisla by spadala spíše do matematiky, i když převod mezi číselnými soustavami a sčítání vyžaduje znalost jistého postupu, ale př́liš nenaplňuje představu o algoritmické úloze. (Ve verzi testu 2015 již uvedena není.) Úloha zařazená do kategorie Zpracování textu (viz dále) není ani algoritmická, ani netestuje uživatelské schopnosti, jde spíše o záležitost typografie.

Dotazovali jsme se jedné $\mathrm{z}$ autorek testu, proč byly vybrány právě tyto úlohy a zda vycházely z nějakého IT kurikula - nějakého vzdělávacího plánu. Dozvěděli jsme se, že úlohy byly vybrány za účelem otestovat použití terminologie, algoritmické a uživatelské dovednosti studentů $\mathrm{v}$ tradičním a netradičním prostředí, jejich dovednosti $\mathrm{v}$ různých oblastech informatiky, jak dokážou rozpoznat tentýž algoritmus realizovaný v různých prostředích, jejich schopnosti a prrístupy $\mathrm{k}$ řešení problémů. (Csernoch, 2015c)

\section{Analýza vybraných úloh}

Není možné podrobně popisovat, rozebírat a komentovat všechny úlohy testu, bylo by to nad rámec rozsahu článku. Ukažme si pouze tři, které byly obzvláště zajímavé, at' už v pozitivním či negativním smyslu.

\section{1 Úloha na tabulky}

Tato úloha je zařazována do testů opakovaně, její řešení je podrobně diskutováno např. v článku (Csernoch \& Biro, 2014b). Jde o úlohu testující algoritmické schopnosti studentů v netradičním prostředí tabulkových kalkulátorů, bohužel studenti neměli moc šancí tyto schopnosti ukázat, nebot' neznali potřebné "excelovské" funkce.

“Odpovězte na otázky a) - e) použitím vzorců tabulkového procesoru, otázku f) vyjádřete slovně."

a) Jaké je hlavní město největší země?

b) Jaká je celková hustota zalidnění těchto zemí?

c) Kolik afrických zemí je v tabulce?

d) Jaká je průměrná populace zemí, jejichž rozloha je menší než G2?

e) Kolik zemí má větší rozlohu než G2?

f) Co bude výsledkem následujícího vzorce? Odpovězte větou $\{=\operatorname{SUMA}($ KDYŽ(B2:B236="Evropa",KDYŽ(ZLEVA(A2:A236)="A",1)))\}

(Csernoch \& Biro, 2014b) 


\begin{tabular}{|c|c|c|c|c|c|c|c|}
\hline 4 & A & B & C & D & $\mathrm{E}$ & $\mathrm{F}$ & G \\
\hline 1 & Country & Continent & Capital & Area & $\begin{array}{l}\text { Population } \\
\text { (thousand) }\end{array}$ & & \\
\hline 2 & Afghanistan & Asia & Kabul & 647500 & 27756 & & \\
\hline 3 & Albania & Europe & Tirana & 28748 & 3545 & & \\
\hline 4 & Algeria & Africa & Algiers & 2381740 & 32278 & & \\
\hline 5 & American Samoa & Oceania & Pago Pago & 199 & 69 & & \\
\hline 6 & Andorra & Europe & Andorra la Vella & 468 & 68 & & \\
\hline 7 & Angola & Africa & Luanda & 1246700 & 10593 & & \\
\hline 8 & Anguilla & America & The Valley & 102 & 12 & & \\
\hline 233 & Yemen & Asia & Sanaa & 527970 & 18701 & & \\
\hline 234 & Yugoslavia & Europe & Belgrade & 102350 & 10657 & & \\
\hline 235 & Zambia & Africa & Lusaka & 752614 & 9959 & & \\
\hline 236 & Zimbabwe & Africa & Harare & 390580 & 11377 & & \\
\hline
\end{tabular}

Obr. č. 1: Tabulka k algoritmické úloze

Učitelé dali této úloze důležitost 37,3\%, predikci úspěšnosti 11,0\%, studenti odhadli své schopnosti práce s tabulkami na $63,6 \%$.

Úloha jako celek dopadla katastrofálně (viz Tab 2), nenulovou úspěšnost 18,6\% měla podotázka f) a též řešení podotázky c) bylo úspěšné na $8,5 \%$.

Podotázka a) měla oproti autorskému řešení ještě alternativní řešení, které nebylo bráno v úvahu, nebot' je "extrémně komplikované" (Csernoch, 2015d), nicméně to na výsledek testu nemělo žádný dopad, nebot' nikdo z českých účastníků toto, ani jiné správné řešení neuvedl.

\begin{tabular}{|l|c|c|c|}
\hline Komplexní úloha na tabulky & Úspěšnost & Neřešilo & Správně \\
\hline Všichni studenti dohromady & $5,08 \%$ & 18 & 0 \\
\hline Studenti ITV dohromady & $2,70 \%$ & 15 & 0 \\
\hline Studenti ITV, ZČU & $1,96 \%$ & 10 & 0 \\
\hline Studenti ITE, JČU & $9,09 \%$ & 3 & 0 \\
\hline Studenti ITV, JČU & $3,33 \%$ & 5 & 0 \\
\hline
\end{tabular}

Tab. č. 2: Výsledky úlohy na tabulky 


\section{2 Úloha z kategorie Algoritmizace}

"Co dělá následující program?" (Csernoch \& Biro, 2014)

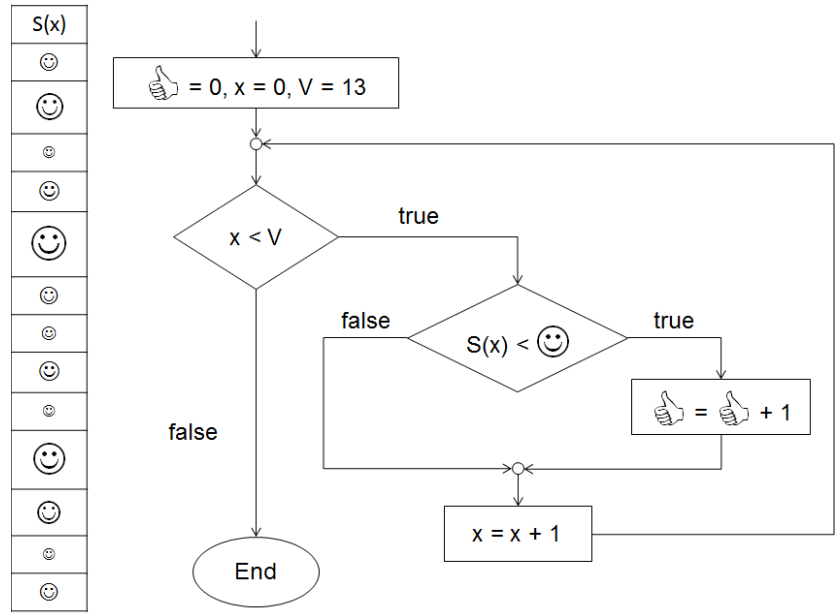

Obr. č. 2: Vývojový diagram úlohy

Učitelé předpovídali $11,1 \%$ úspěšnost úlohy, přičemž důležitost přiřadili pouze $28,9 \%$, což je překvapující. Přitom zrovna tato úloha testuje algoritmické dovednosti. Studenti se odhadli na 37,3\%, ale uspěli pouze na 1,69 \%. Detailní výsledky úlohy jsou uvedeny v Tab 3 .

\begin{tabular}{|l|c|c|c|}
\hline Výsledky úlohy & Úspěšnost & Neřešilo & Správně \\
\hline Všichni studenti dohromady & $1,69 \%$ & 29 & 1 \\
\hline Studenti ITV dohromady & $2,70 \%$ & 18 & 1 \\
\hline Studenti ITV ZČU & $5,88 \%$ & 9 & 1 \\
\hline Studenti ITE JČU & $0,00 \%$ & 11 & 0 \\
\hline Studenti ITV JČU & $0,00 \%$ & 9 & 0 \\
\hline
\end{tabular}

Tab. č. 3: Výsledky algoritmické úlohy

\section{3. Úloha z oblasti Zpracování textu}

Zadání úlohy, jejíž text byl celý v mad’arštině, bylo následující:

“ Analyzujte následující žákovskou práci v textovém editoru (použití cizího jazyka je záměrné). $\mathrm{V}$ tabulce dole označte $\times$ správnou odpověd' nebo typ chyby, v posledním řádku tabulky chybu upřesněte, o jakou chybu jde.”. (Csernoch \& Biro, 2014)

$\mathrm{V}$ textu bylo vyznačeno 18 míst, u nichž se měla zjišt'ovat správnost (formátovací značky a další neviditelné znaky byly zobrazeny). K dispozici byla tabulka obsahující 
5 nedisjunktních kategorií chyb: chyba zalomení textu, formátovací chyba, syntaktická chyba, sémantická chyba a typografická chyba.

Použitá mad'arština účastníky možná vyděsila, ale nehrála roli, nebot' označené partie textu, jejichž korektnost se klasifikovala, byly takové, že jazyk nebyl při řešení podstatný.

Úloha byla poněkud neobvyklá, nebot' jak se v pozdější diskusi ukázalo, studenti nebyli zvyklí "zpracovávat" text tímto způsobem, většinou formátovali daný text dle jistých požadavků či vytvářeli komplexnější projekt. A mnozí sice odhalili chyby v daném textu, ale nebyli schopni provést jejich klasifikaci. Někteř́ se úlohou nezabývali, nebot' byli v časovém presu, a někteří úlohu neřešili, protože je to nebavilo.

Učitelé dali úloze důležitost $45,0 \%$, predikci stanovili na $17,7 \%$, prričemž studenti odhadli své schopnosti ve zpracování textů na $75,8 \%$, úspěšnost studentů byla jen $18,1 \%$.

\section{Celkové výsledky testu 2014 za Českou republiku}

Následující tabulka uvádí výsledky testu v jednotlivých kategoriích:

\begin{tabular}{|l|r|r|r|r|r|}
\hline Test TAaAS 2014 & \multicolumn{1}{|c|}{ Soubory } & \multicolumn{1}{c|}{ Č́sla } & \multicolumn{1}{c|}{ Tab } & \multicolumn{1}{c|}{ Text } & \multicolumn{1}{c|}{ Alg } \\
\hline Učitelé & 35,16 & 32,26 & 7,37 & 15,38 & 37,72 \\
\hline Studenti dohromady & 30,51 & 9,89 & 4,36 & 18,12 & 27,06 \\
\hline Studenti ITV ZČU & 24,71 & 20,59 & 1,68 & 14,48 & 14,03 \\
\hline Studenti ITE JČU & 31,82 & 3,03 & 7,79 & 18,88 & 22,45 \\
\hline Studenti ITV JČU & 34,00 & 8,33 & 2,86 & 20,38 & 21,43 \\
\hline Predikce & 44,08 & 10,45 & 9,67 & 17,05 & 20,87 \\
\hline
\end{tabular}

Tab. č. 4: Celkové výsledky českých účastníků

Pro názornější představu si ukažme i grafické vyhodnocení:

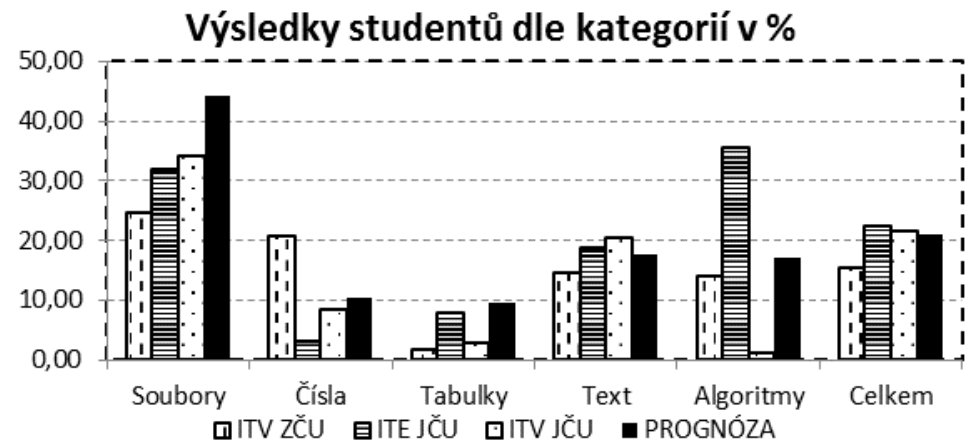

Obr. č. 3: Výsledky jednotlivých kategorii úloh 


\section{Statistické zpracování výsledků}

Přibližně $70 \%$ zúčastněných českých studentů skládalo maturitu z informatiky (informatických předmětů). $Z$ všeobecného dotazníku (součást testu) je vidět, že maturita z IT zahrnovala předměty:

- informační a komunikační technologie,

- programování,

- práce s kancelářskými aplikacemi,

- počítačové sítě,

- počítačová grafika,

- operační systémy,

- praktická závěrečná práce.

Maturity z informatiky byly ústní, písemné či kombinované.

Průměrná známka činila 2,12 a hned na první pohled to vypadalo, že naprosto nehraje roli, zda student maturoval z informatiky či nikoliv, a že výsledky testu jsou na hodnocení z maturity nezávislé.

Stanovili jsme následující hypotézy:

- H1: Výsledky testu nesouvisejí s absolvováním maturity z informatiky.

- H2: Výsledky testu souvisejí s hodnocením u maturity z IT - lepší známka $\mathrm{z}$ maturity vede $\mathrm{k}$ lepším výsledků testu.

- H3: Studenti bakalářského oboru "Informační technologie a e-learning" (ITE) dosáhli v testu lepších výsledků než studenti oboru "Informační technologie se zaměřením na vzdělávání (ITV) - jejich průměrná úspěšnost je větší.

- H4: Učitelé uspěli lépe než studenti - jejich průměrná úspěšnost je větší než průměrná úspěšnost studentů

Všechny hypotézy byly testovány na standardní hladině významnosti $\alpha=0,05$; takže možnost nesprávného príietí či zamítnutí nulové hypotézy byla $5 \%$.

Testování H1: Jako nulová hypotéza byla stanovena hypotéza o nezávislosti proměnných "absolvování maturity z IT" a výsledek testu. Výsledky informatického testu byly diskretizovány do 5 nominálních hodnot, $\mathrm{k}$ ověření hypotézy byl použit chí-kvadrát test dobré shody. Zjišsěná hodnota $\mathrm{p}$-value $=0,9712$ ukazuje, že nelze zamítnout hypotézu o nezávislosti.

Testování H2: Jako nulová hypotéza byla stanovena hypotéza o nezávislosti proměnných. Obě proměnné (známka z maturity a úspěšnost $v$ testu) byly spojité, takže byl použit Pearsonův korelační koeficient, jehož hodnota vyšla $-0,326$, přičemž p-value $=0,1362$, což ukazuje, že prípadná korelace není statisticky významná a nelze tedy zamítnout hypotézu o nezávislosti.

Testováni H3: Jako nulová hypotéza byla stanovena hypotéza o shodě průměrných hodnot výsledků v obou skupinách studentů. K ověření byl použit Studentův t-test pro dva nezávislé výběry, nejdříve ovšem bylo testováno, zda skupiny mají stejný rozptyl (byl použit F-test), a pokud tomu tak nebylo, byl použit Welchův test.

Testování bylo prováděno na úrovni výsledku celého testu, kdy nebyl zjištěn podstatný rozdíl mezi studenty ITE a ITV (p-value $=0,1459$ ), a dále zvlášt' pro jednotlivé kategorie úloh. Ukázalo se, že v kategorii Čisla dosáhli významně vyššího průměru 
studenti ITV a naopak v kategorii Algoritmizace a Tabulky dosáhli významně vy̌šśho průměru studenti ITE, v kategorí́ch Soubory a Text nebyl zjištěn významný rozdíl.

Testování H4: Bylo rozhodně zajímavé zjištovat rozdíly mezi výsledky učitelů a studentů. Byly ověřovány vlastně 3 hypotézy, nebot' ze zúčastněných studentů byly vytvořeny 3 výběry: studenti ITE tvořili výběr $S a$, skupina studentů ITV představovala výběr $\mathrm{Sb}$, přičemž všichni studenti dohromady byli bráni jako výběr Sc. Učitelé vždy figurovali jako jeden výběr, který byl postupně porovnáván s každým ze studentských výběrů $\mathrm{Sa}, \mathrm{Sb}, \mathrm{Sc}$.

Byla testována nejprve nulová hypotéza o shodě průměrných hodnot výsledků testu obou porovnávaných skupin (výběrư), k ověřování byl vždy použit Welchưv test, nebot' F-test každé dvojice výběrů nepotvrdil shodu rozptylů. V případě vyvrácení hypotézy o shodě průměrů byly pak testovány jednostranné hypotézy tvrdící, že „průměrné výsledky učitelì jsou větši než průměrné výsledky vybrané skupiny studentü “.

Testováni H4a: Byly zjištovány významné rozdíly mezi výsledky učitelů a studentů ITE. Hypotézu o shodě průměrných výsledků se nepodařilo vyvrátit ( $p$-value $=0,2542$ ), tudíž se nepotvrdilo, že učitelé dosáhli lepších výsledků v testu.

Testování H4b: Byly zjištovány rozdíly mezi učiteli a studenty ITV (budoucími učiteli), nulová hypotéza o shodě byla vyvrácena ( $\mathrm{p}$-value $=0,0227)$; jednostranná hypotéza tvrdící, že učitelé dosáhli lepších výsledků tj. většího průměrného hodnocení než studenti ITV, byla potvrzena (s p-value $=0,0113)$.

Testování H4c: Byly zjišt'ovány rozdíly mezi učiteli a všemi studenty. I v tomto př́ípadě byla nulová hypotéza o shodě průměrů vyvrácena $(p-v a l u e ~=0,0480)$, provedený jednostranný t-test potvrdil, že učitelé ve srovnání $\mathrm{s}$ výběrem všech studentů dosáhli většího průměrného hodnocení tj. lepších výsledků než studenti (s p-value $=0,0240)$.

\section{Diskuse výsledků a závěr}

Detailní analýza dat testu ukazuje, že výsledky našich studentů nejsou dobré, rozhodně ne tak dobré, jak jsme čekali a jak bychom očekávali od vysokoškolských studentů IT oborů. Nicméně ani výsledky testovaných učitelů nejsou dobré, což svědčí o tom, že se testovalo něco, co se běžně u nás neučí.

Toto zjištění potvrzuje skutečnost, že studenti neodhadli své schopnosti a dovednosti ve zvládání jednotlivých kategorií úloh. Vypadá to, že se většinou značně přecenili, nicméně jejich odhady vycházely $\mathrm{z}$ dosavadních zkušeností s řešením úloh $\mathrm{z}$ uvedených testovaných kategorií a vede $\mathrm{k}$ závěru, že dané úlohy byly trochu mimo rámec běžných ŠVP, což se potvrdilo v diskuzi se studenty.

Testové úlohy sice spadaly do kategorií, které patří do informatického kurikula, ale díky různým ŠVP a neakurátním standardům a výstupům RVP je testování problematické. V testu se vyskytovaly úlohy, které nezvládli ani zúčastnění učitelé. A pokud učitel "neumí" určitou problematiku, pak ji nejspíš ani nevyučuje. Pokud se určité téma ve škole nevyučuje, pak ho student ovládá, pouze pokud se ho naučil sám jinde.

Znovu se tak dostáváme $\mathrm{k}$ známé otázce, co se vlastně ve školách $\mathrm{v}$ informatice vyučuje, ale i k problému, že informatika je často vyučována neaprobovanými učiteli, jejichž představa o oboru může být pokřivená (Stuchlíková, I. \& Janík, T. et al., 2015)

Nalezli jsme jisté odlišnosti v úrovni znalostí studentů různých oborů IT. Na základě předchozích zjiššění lze též usoudit, že mezi znalostmi učitelů a studentů oboru ITE není 
podstatný rozdíl, naopak praktikující učitelé dosahují vyššího skóre, než budoucí učitelé. Nicméně počet zúčastněných studentů byl poměrně malý a byly zastoupeny pouze tři obory ze dvou univerzit, výsledky nelze brát jako obecně relevantní.

Obsahová validita testu je sporná, úlohy nepokrývají danou problematiku a vyjdemeli ze stanovení důležitosti otázek testu zúčastněnými učiteli, ze 13 otázek by prošlo do užšího výběru sotva 7, prričemž bylo prokázáno, že mezi učiteli střední a základních škol nebyl statisticky významný rozdíl ve stanovení důležitosti otázek. Co se reliability testu týče, Cronbachovo alfa studentských účastníků činilo 0,24 , a to není príznivé.

Daný test tedy nelze univerzálně použít ke zjišstování úrovně IT znalostí, na základě výsledkủ testu nemá smysl provádět srovnání ani v rámci Česka, ani na mezinárodním poli. (Výsledky ostatních zúčastněných států jsme od autorů testu stejně nezískali).

Dlouhodobý záměr vzdělávání a rozvoje vzdělávací soustavy České republiky na období 2015-2020 slibuje "provést obsahové úpravy rámcových vzdělávacích programů (RVP) v středním vzdělávání tak, aby zdůrazňovaly očekávané výstupy v rozhodujících složkách vzdělávání, směřovaly ke zřetelnějšímu vymezení cílů (napřs. ve formě standardů) v jednotlivých RVP, podpořily matematické, jazykové, ICT a polytechnické vzdělávání, zahrnovaly popisy očekávaných úrovní znalostí, dovedností a postojů vytvářejících předpoklady pro udržitelný rozvoj". (MŠMT, 2015)

Brzy snad nebudeme srovnávat nesrovnatelné alespoň uvnitř Česka a možná se dočkáme i lepších znalostí našich studentů.

\section{Literatura}

Crawley, M. J. (2013). The R book. 2nd ed. Chichester: Wiley.

Csernoch, M, Biró, P., Abari, K., Máth, J. (2015a). Understanding Algorithms in

Different Presentations, Acta Didactica Napocensia, 8 (4), 1-12.

Csernoch, M., Biró, P.(2014a). TAaAS test 2014. University of Debrecen.

Biró, P., Csernoch, M., Máth, J., Abari, K. (2015b). Measuring the Level of Algorithmic Skills at the End of Secondary Education in Hungary. Procedia - Social and Behavioral Sciences [Online]. DOI: 10.1016/j.sbspro.2015.01.553. Dostupné z WWW:

<http://www.sciencedirect.com/science/article/pii/S187704281500590X >

Csernoch, M. (2015c). Emailová korespondence s autorem článku ze dne 1. 7. 2015.

Csernoch, M. (2015d). Emailová korespondence s autorem článku ze dne 8. 9. 2015.

Csernoch, M., Biró, P. (2014b). Spreadsheet misconceptions, spreadsheet errors.

Oktatáskutatás határon innen és túl. HERA Évkönyvek I., ed. Juhász Erika, Kozma

Tamás, Szeged : Belvedere Meridionale, p. 370-395.

Dagdilelis, V., Satratzemi, M, Evangelidis, G. (2004). Introducing Secondary Education

Students to Algorithms and Programming. Education and Information Technologies.

Heidelberg: Springer International Publishing, s. 159-173.

Hendl, J. (2006). Přehled statistických metod zpracování dat: analýza a metaanalýza dat. Vyd. 2., opr. Praha: Portál.

Chráska, M. (2007). Metody pedagogického výzkumu: základy kvantitativního výzkumu.

Praha: Grada. Pedagogika.

McCormack, A. (2010). E-skills Manifesto [online]. Brusel:European Schoolnet, 2010.

Available from: http://files.eun.org/eskillsweek/manifesto/e-skills_manifesto.pdf

Stuchlíková, I. \& Janík, T. et al. (2015). Oborové didaktiky:vývoj-stav-perspektivy.

Brno: Masarykova univerzita. 
Dlouhodobý zámér vzdèlávání a rozvoje vzdèlávací soustavy České republiky na období 2015-2020. (2015). Praha: MŠMT, 2015. Dostupné z WWW:

<http://www.msmt.cz/file/35167_1_1/>

Upravený RVPZV se zapracovanými změnami 290313 (2013). Praha: MŠMT.

Dostupné z WWW: <http://www.nuv.cz/file/318/>

Rámcový vzdělávaci program pro gymnázia (2007a). Praha: MŠMT. Dostupné z WWW:

$\langle\mathrm{http} / /$ www.msmt.cz/file/10427_1_l>

RVP pro obor 63-41-M/01 Ekonomika a podnikání. (2007b). Praha: MŠMT. Dostupné z WWW:

<http://zpd.nuov.cz/RVP/ML/RVP 6341M01 Ekonomika a podnikani.pdf> RVP pro obor 26-41-M/01 Elektrotechnika (2007d). Praha: MŠMT.

Dostupné z WWW: 〈http://zpd.nuov.cz/RVP/ML/RVP 2641M01 Elektrotechnika.pdf> RVP pro obor 23-41-M/01 Strojírenství (2007e). Praha: MŠMT, 2007.

Dostupné z WWW: 〈http://zpd.nuov.cz/RVP/ML/RVP 2341M01 Strojirenstvi.pdf>

ECDL Sylabus Core 5.0 (2010). ECDL Foundation.

Dostupné z WWW: http://www.ecdl.cz/sylaby.php 